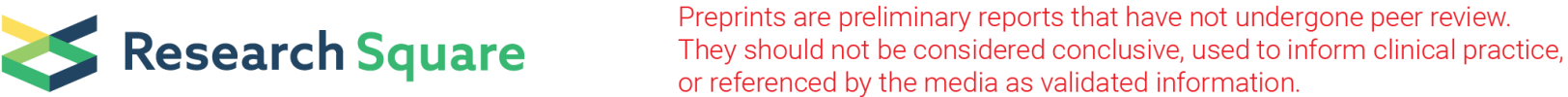

\section{Can judgments according to case fatality rate be correct all the time during epidemics? Some lessons from Coronavirus 2019-nCoV case fatality rate index in Iran}

\section{Bakhtiar Piroozi ( $\sim$ bpiroozi@gmail.com )}

Kurdistan University of Medical Sciences https://orcid.org/0000-0002-6973-5764

Ghobad Moradi

Kurdistan University of Medical Sciences

Amjad Mohamadi-Bolbanabad

Kurdistan University of Medical Sciences

Hossein Safari

Iran University of Medical Sciences

Research article

Keywords: Coronavirus, Coronavirus COVID-19, Case Fatality Rates, Outbreak, Iran

Posted Date: March 25th, 2020

DOl: https://doi.org/10.21203/rs.3.rs-19296/v1

License: (c) (1) This work is licensed under a Creative Commons Attribution 4.0 International License.

Read Full License 


\section{Abstract}

Background: Coronavirus 2019-nCoV was first identified in China in 2019. One of the most important indices noticed by experts, policymakers and managers which is daily evaluated in epidemics and a lot of judgments are made based on it, is case fatality rate (CFR) index of the disease. CFR can change during epidemics. This study aims to calculate CFR index for nCov-2019 in Iran and answer the following question: Is it right to base judgment on CFR all the time during epidemics and is it right to judge based on that since the outbreak of an epidemic?

Methods: This research is a descriptive study. Its required data was obtained from the website of The Ministry of Health and Medical Education of Iran from February $20^{\text {th }} 2020$ until March $14^{\text {th }} 2020$. CFR index was calculated when the death toll of a disease is divided by the total number of people infected by that disease. Excel 2013 software was used to a1nalyze the data.

Results: According to the findings of this study, In Iran, until March $14^{\text {th }} 2020,11364$ people have been infected by Coronavirus 2019-nCoV and 514 people died of it. CFR index had a descending trend and it was $100 \%, 18.6 \%, 8.8 \%, 3.1 \%, 3.3 \%, 4.5 \%$ on the first, fifth, tenth, fifteenth, twentieth and twenty fifth day, respectively.

Conclusion: In emerging epidemics, an index must not be based to judge a health system's performance until that epidemics condition has not been clarified. It would be suggested that in the outbreak of an epidemic, specifically emerging diseases, CFR must not be the base of judgment. Making judgments, specifically, in the outbreak of emerging epidemics based on fatality rate can lead to an information bias.

\section{Background}

Coronaviruses are a big family of viruses. Some coronaviruses cause diseases in human and some others in animals such as bats and camels. Human coronaviruses typically cause mild diseases. Sometimes, animal coronaviruses evolve and spread among humans and cause severe diseases; Severe Acute Respiratory Syndrome (SARS) in 2002 and Middle East Respiratory Syndrome (MERS) in 2012 were among such cases [1-3]. Coronavirus 2019-nCoV is a new species of this virus which had not been identified in human before. This virus was first identified in Wuhan city in China in December of 2019 and had a widespread outbreak. This virus had a more widespread outbreak in China and until March 14th 2020, in more than 130 countries, positive cases of that were reported [1, 4]. According to the published world statistics, the number of identified people infected by coronavirus was 145332 (until March 14th 2020) out of which 70921 people were recovered and 5416 people died; the reported fatality rate of this disease among people has been $3.7 \%$ so far. According to the existing evidences, the emergence of this disease in almost $91 \%$ of people is mild and in $9 \%$ is severe [5].

In Iran, the first positive case of Coronavirus 2019-nCoV was confirmed in February 20th 2020 in Qom city and until March 14th 2020, the total number of cases in the country was 11364 people out of which 3529 
people were recovered and 514 people died [6]. According to world statistics, up to now, Iran has reported the most positive cases of coronavirus after China (80815) and Italy (17660) [5].

One of the most important indices noticed by healthcare experts, policymakers and managers in epidemics, specifically in emerging epidemics, is CFR index. This index is obtained by dividing the death toll caused by a disease by the total number of people infected by the same disease. In most cases, this index is utilized for specific epidemics of acute diseases such as cholera during which all patients are under treatment in a specific period of time and this makes it possible to calculate the death toll caused by a disease. The index of CFR indicates the fatality potential of a disease and it just includes the proportion of death toll to the number of patients. This index can be used to describe fatality trend and its general changes, making decisions for healthcare priorities, resource allocation, planning intervention programs and evaluation and refining problems and plans for public health and it can terrify a society in case of emerging epidemics when it is reported high [8, 7]. In Iran and many other countries, in the outbreak or in the middle of Covid19, some interpretations were put on CFR. These interpretations were sometimes published on social news networks and cause fear among people and put pressure on countries' health system. In Iran, given the fact that in the outbreak, this index was high, there were different interpretations on the fatality rate of this disease and based on that, different judgments were made concerning the health systems. In this study, we were in search of this index trend during different time intervals of this epidemic's outbreak. In other words, this study made an effort to answer the following question: Is it right to base judgment on CFR at each stage during epidemics and is it right to judge based on that since the outbreak of an epidemic?

\section{Methods}

This is a descriptive study. The required data for it was obtained from the website of The Ministry of Health and Medical Education of Iran from February 20th 2020 until March 14th 2020 (6). This data was daily published. CFR has been obtained by dividing the death toll caused by a disease by the total number of people infected by the same disease [8] (formula 1).

Case Fatality Rate=

\section{Total death from a special disease}

\section{Tota case of that disease}

Eq. (1)

It is worth mentioning that since the denominator of this fraction is the number of the patients referring to medical centers; it is possible for this CFR index not to be correct. Excel 2013 was used to analyze the data.

\section{Results}


As can be seen in Table 1, until March 14th 2020, the total number of the identified infected cases in Iran was 11364 out of which 3529 people have been recovered and 514 patients died. This table shows the number of the identified cases since the outbreak and the number of perished people on different days. The index of CFR has had a descending trend such that the amount of this index on first, fifth, tenth, fifteenth, twentieth and twenty fifth day was $100 \%, 18.6 \%, 8.8 \%, 3.1 \%, 3.3 \%$ and $4.5 \%$ respectively. 
Table 1

Confirmed Cases and Deaths by Coronavirus 2019-nCoV in Iran (as of March 14th 2020)

\begin{tabular}{|c|c|c|c|c|c|c|c|}
\hline ID & Date & $\begin{array}{l}\text { New } \\
\text { cases }\end{array}$ & $\begin{array}{l}\text { Total } \\
\text { Cases }\end{array}$ & $\begin{array}{l}\text { New } \\
\text { Deaths }\end{array}$ & $\begin{array}{l}\text { Total } \\
\text { Deaths }\end{array}$ & $\begin{array}{l}\text { Total } \\
\text { Recovered }\end{array}$ & $\begin{array}{l}\text { Case Fatality } \\
\text { Rate }\end{array}$ \\
\hline 1 & $\begin{array}{l}\text { February 20, } \\
2020\end{array}$ & 2 & 2 & 2 & 2 & 0 & 100.0 \\
\hline 2 & $\begin{array}{l}\text { February } 21, \\
2020\end{array}$ & 3 & 5 & 0 & 2 & 0 & 40.0 \\
\hline 3 & $\begin{array}{l}\text { February 22, } \\
2020\end{array}$ & 13 & 18 & 2 & 4 & 0 & 22.2 \\
\hline 4 & $\begin{array}{l}\text { February 23, } \\
2020\end{array}$ & 10 & 28 & 1 & 5 & 0 & 17.9 \\
\hline 5 & $\begin{array}{l}\text { February } 24, \\
2020\end{array}$ & 15 & 43 & 3 & 8 & 0 & 18.6 \\
\hline 6 & $\begin{array}{l}\text { February 25, } \\
2020\end{array}$ & 18 & 61 & 4 & 12 & 0 & 19.7 \\
\hline 7 & $\begin{array}{l}\text { February 26, } \\
2020\end{array}$ & 34 & 95 & 3 & 15 & 25 & 15.8 \\
\hline 8 & $\begin{array}{l}\text { February } 27, \\
2020\end{array}$ & 46 & 141 & 7 & 22 & 54 & 15.6 \\
\hline 9 & $\begin{array}{l}\text { February } 28, \\
2020\end{array}$ & 104 & 245 & 4 & 26 & 64 & 10.6 \\
\hline 10 & $\begin{array}{l}\text { February 29, } \\
2020\end{array}$ & 143 & 388 & 8 & 34 & 73 & 8.8 \\
\hline 11 & $\begin{array}{l}\text { March 1, } \\
2020\end{array}$ & 205 & 593 & 9 & 43 & 123 & 7.3 \\
\hline 12 & $\begin{array}{l}\text { March 2, } \\
2020\end{array}$ & 385 & 978 & 11 & 54 & 175 & 5.5 \\
\hline 13 & $\begin{array}{l}\text { March 3, } \\
2020\end{array}$ & 523 & 1501 & 12 & 66 & 291 & 4.4 \\
\hline 14 & $\begin{array}{l}\text { March 4, } \\
2020\end{array}$ & 835 & 2339 & 11 & 77 & 144 & 3.3 \\
\hline 15 & $\begin{array}{l}\text { March 05, } \\
2020\end{array}$ & 586 & 2922 & 15 & 92 & 408 & 3.1 \\
\hline 16 & $\begin{array}{l}\text { March 06, } \\
2020\end{array}$ & 591 & 3513 & 15 & 107 & 331 & 3.0 \\
\hline 17 & $\begin{array}{l}\text { March 07, } \\
2020\end{array}$ & 1234 & 4747 & 16 & 124 & 913 & 2.6 \\
\hline
\end{tabular}




\begin{tabular}{|llllllll|}
\hline ID & Date & $\begin{array}{l}\text { New } \\
\text { cases }\end{array}$ & $\begin{array}{l}\text { Total } \\
\text { Cases }\end{array}$ & $\begin{array}{l}\text { New } \\
\text { Deaths }\end{array}$ & $\begin{array}{l}\text { Total } \\
\text { Deaths }\end{array}$ & $\begin{array}{l}\text { Total } \\
\text { Recovered }\end{array}$ & $\begin{array}{l}\text { Case Fatality } \\
\text { Rate }\end{array}$ \\
\hline 18 & $\begin{array}{l}\text { March 08, } \\
\text { 2020 }\end{array}$ & 1076 & 5823 & 21 & 145 & 1669 & 2.5 \\
\hline 19 & $\begin{array}{l}\text { March 09, } \\
\text { 2020 }\end{array}$ & 743 & 6566 & 49 & 194 & 2134 & 2.9 \\
\hline 20 & $\begin{array}{l}\text { March 10, } \\
\text { 2020 }\end{array}$ & 595 & 7161 & 43 & 237 & 2394 & 3.3 \\
\hline 21 & $\begin{array}{l}\text { March 11, } \\
\text { 2020 }\end{array}$ & 881 & 8042 & 54 & 291 & 2731 & 3.6 \\
\hline 22 & $\begin{array}{l}\text { March 12, } \\
\text { 2020 }\end{array}$ & 958 & 9000 & 63 & 354 & 2959 & 3.9 \\
\hline 23 & $\begin{array}{l}\text { March 13, } \\
\text { 2020 }\end{array}$ & 1075 & 10075 & 75 & 429 & 3276 & 4.2 \\
\hline 24 & $\begin{array}{l}\text { March 14, } \\
\text { 2020 }\end{array}$ & 1289 & 11364 & 85 & 514 & 3529 & 4.5 \\
\hline
\end{tabular}

Table 1 Here

Figure 1 indicates the time course of the number of people infected by Coronavirus 2019-nCoV and its CFR in Iran.

Figure 1 Here

\section{Discussion}

According to the results of this study, by the passage of time since the identification of the first case infected by Coronavirus 2019-nCoV and increasing the number of positive cases of coronavirus, the index of CFR decreases and as the time passes more, the amount of this index approaches its real amount. In order to calculate the real amount of CFR index, it is necessary to identify all the cases infected by Covid 19 and the death toll caused by that; while currently, the statistics belonging just to those infected patients who refer to medical centers is recorded. The evidences indicate that more than $90 \%$ of people infected by Coronavirus 2019-nCoV show mild symptoms of the disease (5) and a fraction of this population may not refer to medical centers and consequently, their data is not recorded. The findings of some studies reveal that the CFR of some emerging diseases such as Ebola decreases over time and this can be the result of creating and increasing the required facilities and infrastructures like laboratories and hospital beds and personnel's enhanced experience [9]. On the first days of diagnosis, given the identification of cases most of which led to death, a lot of pressures were on Iran's Health System and different interpretations were put forward regarding this issue. During the outbreak this epidemic, the main criticism Iran faced was the probability of its inability to identify this virus. One of the other 
interpretations was that this virus species may be different from the basic species and it may be more fatal. These interpretations caused a lot fear among people and put a great deal of pressure on managers and the Health System's experts for decision making.

Therefore, making decisions just based on CFR index during the outbreak of epidemics is not right and it may result in overestimates and might be confusing and threaten the mental health of a society. More accurate calculation of this index requires the passage of time and of course, exact determination of its amount needs identification of its natural history. The definition of an appropriate index in epidemics is of great significance. In emerging diseases, CFR index must be interpreted carefully and its hasty calculation and interpretation can put a lot pressure on Health Systems and lead to wrong and unprofessional decisions on the side of those who are in charge of healthcare.

\section{Conclusion}

It would be suggested that, during the outbreak of epidemics, specifically, emerging diseases, judgments not be based on CFR. It is expected to identify the most emerging epidemics during their outbreak when they are severe and probably lead to death. Making judgments based on fatality, specifically, in the outbreak of emerging epidemics can lead to information bias. It should be noticed that, after the identification of the first cases, gradually, as Health Systems' ability and awareness rise, this fatality rate decreases.

\section{References}

1.

Mahase E. Coronavirus: covid-19 has killed more people than SARS and MERS combined, despite lower case fatality rate. BMJ. 2020;368:m641.

2.

de Wit E, van Doremalen N, Falzarano D, Munster VJ. SARS and MERS: recent insights into emerging coronaviruses. Nat Rev Microbiol. 2016;14(8):523-34.

3.

Hilgenfeld R, Peiris M. From SARS to MERS: 10 years of research on highly pathogenic human coronaviruses. Antiviral Res. 2013 Oct;100(1):286-95.

4.

Lai C-C, Shih T-P, Ko W-C, Tang H-J, Hsueh P-R. Severe acute respiratory syndrome coronavirus 2 (SARSCoV-2) and corona virus disease-2019 (COVID-19): the epidemic and the challenges. Int J Antimicrob Agents. 2020 Feb;17:105924.

5 .

Worldometers

2020

Worldometers. COVID-19 CORONAVIRUS OUTBREAK. World Meters. 2020. [cited 2020 March 14]. Available from: https://www.worldometers.info/coronavirus/. 
6.

MOHME. Ministry of Health and Medical Education. Tehran, Iran. 2020. [cited 2020 March 14]. Available from: air.ir/ZwqjJao.

7.

Porcheddu R, Serra C, Kelvin D, Kelvin N, Rubino S. Similarity in Case Fatality Rates (CFR) of COVID19/SARS-COV-2 in Italy and China. JIDC. 2020;14(02):125-8.

8.

Lu CY, Lee CY, Kao CL, Shao WY, Lee PI, Twu SJ, et al. Incidence and case-fatality rates resulting from the 1998 enterovirus 71 outbreak in Taiwan. J Med Virol. 2002 Jun;67(2):217-23.

9.

Wang L, Yang G, Jia L, Li Z, Xie J, Li P, et al. Epidemiological features and trends of Ebola virus disease in West Africa. Int J Infect Dis. 2015 Sep;38:52-3.

\section{Declarations}

\section{List of abbreviations}

CFR: Case Fatality Rate

\section{Ethics approval and consent to participate}

This study was approved by the Ethics Committee of Kurdistan University of Medical Sciences. The data of this study is publically available from: https://www.worldometers.info/coronavirus/.

\section{Consent for publication}

Not applicable

\section{Availability of data and materials}

The datasets used and/or analysed during the current study are available from the corresponding author on reasonable request.

\section{Competing interests}

The authors declare no conflict of interest.

\section{Funding}

The deputy of research of Kurdistan University of Medical Sciences has contributed to the funding this research. 
$\mathrm{BP}$ and GM participated in the design of the study. AM, HS and AS were responsible for cleaning data and running statistical analysis and interpretation of the results. BP, GM, HS, AM, and AS were responsible for writing the first draft. Also, BP, GM, HS, AS and AM equally contributed to editing draft versions and accept full responsibility for the content of the manuscript. All authors read and approved the final manuscript.

\section{Acknowledgements}

The authors wish to thank the deputy of research of Kurdistan University of Medical Sciences for approving and supporting this research

\section{Figures}

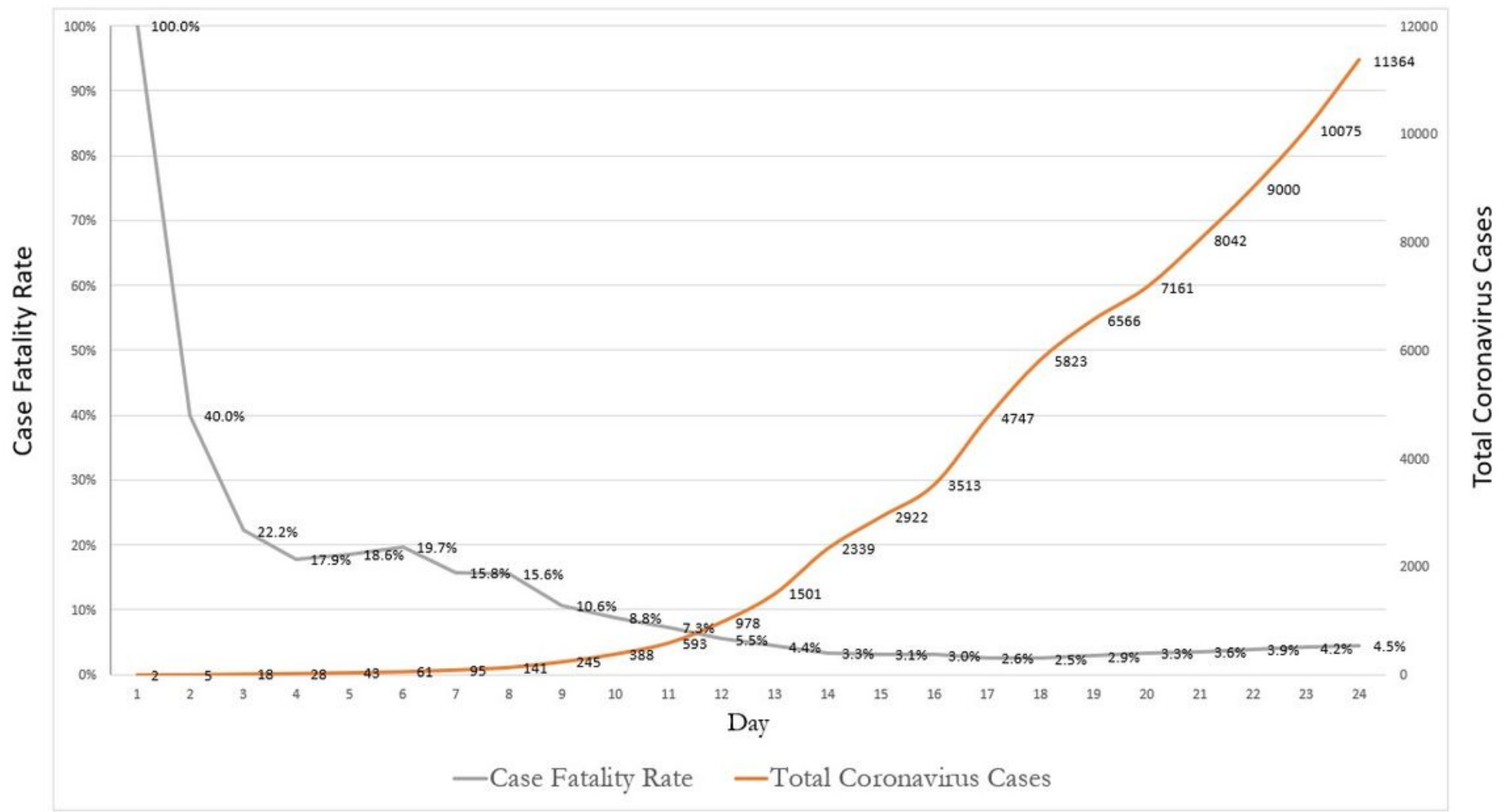

\section{Figure 1}

Total Case and Case Fatality Rate of Coronavirus 2019-nCoV in Iran (as of March 14th, 2020) 